Proc. Estonian Acad. Sci. Biol. Ecol., 2005, 54, 3, 242-248

\title{
A retrospective view of occupational exposure to asbestos-containing dust in a cement factory
}

\author{
Maie Kangur \\ Department of Environmental Health, National Institute for Health Development, Hiiu 42, 11619 \\ Tallinn, Estonia; maie.kangur@tai.ee \\ Received 10 September 2004, in revised form 18 October 2004

\begin{abstract}
A retrospective view of occupational exposure to asbestos-containing dust during the processing of asbestos-cement sheets is presented. Total dust concentrations were determined by the gravimetric method and airborne fibre levels by the phase contrast optical microscope method. All the samples were collected at stationary measuring points (area samples). Airborne fibre and total dust concentrations varied in a large range during processing. The average airborne fibre concentrations at the workplaces were from 0.02 to 4.40 fibres $/ \mathrm{cm}^{3}$ and the average total dust concentrations were
\end{abstract} \\ from 1.20 to $8.60 \mathrm{mg} / \mathrm{m}^{3}$. At the present time asbestos is not used industrially in Estonia.
}

Key words: chrysotile asbestos, total dust, occupational exposure.

\section{INTRODUCTION}

In Estonia cement production was one of the most important branches of the construction industry during the last century. Kunda Cement Factory was established in 1870. At the beginning of 1895, after reconstructions and technological renovations, production of portland cement of local limestone, clay, and sand started. Thousands of workers were exposed to cement dust in their workplaces during the last century. About $500 \mathrm{~kg}$ of cement was used per one inhabitant of Estonia a year in the construction industry during the Soviet period. In 1962 the production of asbestos-cement construction materials (wavy roofing sheets) was establised in this factory. For 33 years asbestos-cement sheets were produced and on average 100 workers were employed in this department.

Wavy roofing sheets were produced of a mixture of portland cement, water, and chrysotile asbestos (10-20\%). Asbestos fibres were separated by wet processing and mixed with cement and water. The mixture was pressed and raw products were formed and hydrothermally hardened. 
Estonia has no asbestos deposits. All the raw asbestos (chrysotile) needed was imported from other parts of the Soviet Union. No exact data on the total amount of imported asbestos are available. The main part of the imported chrysotile asbestos was used for the production of asbestos-cement roofing sheets. During the years 1962-1995 about 6000-7000 tonnes of raw asbestos was used per year and 1.4 million tonnes of roofing sheets were produced. About half of the sheets were exported to the northwestern part of Russia, and approximately 20000 tonnes a year were sold in Estonia at that time (Kangur, 1996; Kangur et al., 1998). According to the existing data about $12-14 \mathrm{~kg}$ of asbestos and asbestos-containing products were used per one inhabitant of Estonia a year during the Soviet period. In 1995 the production of asbestos-cement sheets in Kunda Cement Factory was closed.

Asbestos is a hazardous material. Exposure to asbestos can induce malignant and nonmalignant tumours and asbestosis. Clinical and epidemiologic studies have established incontrovertibly that asbestos causes cancer of the lung, malignant mesothelioma of the pleura and peritoneum, cancer of the larynx, and certain gastrointestinal cancers. Asbestosis is a fibrotic, nonmalignant lung disease caused by inhalation and retention of asbestos fibres and reaction of the lung to these fibres (Parker, 1997; Wagner, 1997; Landrigan et al., 1999). A review of the available evidence indicated that lung cancer can occur as a result of asbestos exposure, in the absence of clinical or histologic asbestosis (Egilman et al., 1996).

In 1992-1995 investigations were carried out about the health status of the workers exposed to dust (portland cement, asbestos cement) in Kunda Cement Factory and local Kunda inhabitants with respect to respiratory organs. The research was performed at the Estonian Institute of Experimental and Clinical Medicine in cooperation with Örebro Medical Hospital in Sweden and the Finnish Institute of Occupational Health. A total of 300 (197 cement and 103 asbestoscement) workers of the cement factory and 130 inhabitants of Kunda were studied. Most of the workers had a long working history (45.3\% more than 20 years). The majority had lived in Kunda for a long time (only $3.7 \%$ up to 4 years). The average age of the studied groups was $44.6 \pm 12.6$ years. Ten cases of pneumoconiosis ( 2 of them in the Kunda town group) and one case of asbestosis were diagnosed. Asbestosis was diagnosed in a worker of the asbestos-cement department, who had been exposed to asbestos-cement dust over 30 years. Chronic bronchitis was diagnosed on $40.8 \%$ (42 cases) of the workers exposed to asbestos-cement dust and $23.4 \%$ (46 cases) of the workers exposed to cement dust (Loogna et al., 1996; Kangur et al., 1998).

In Latvia, for example, the largest enterprise using asbestos for the production of slates (a roof covering material) was the joint stock company Brocenu Siferis, where 13000 to 16000 tonnes of asbestos per year was used in the 1970s-1980s. Air quality measurements at Brocenu Siferis showed the highest concentrations of asbestos fibres in the workplace air ranging from 0.43 to 13.6 fibres $/ \mathrm{cm}^{3}$ but the overall mean was $0.39-4.54$ fibres $/ \mathrm{cm}^{3}$. During the period from 1974 to 1996 data on 33 persons from cement and slate factories were registered in the Latvian State Register as persons having an occupational disease: 7 had asbestosis $(21.2 \%)$, 
12 pneumoconiosis from mixed dust (36.4\%), 10 chronic dust bronchitis (30.3\%), and 4 lung and bronchial tumours (12.1\%) (Eglite et al., 1998).

In Poland about 100000 tonnes of asbestos, containing $90 \%$ of chrysotile, was used annually in the 1970s. This figure decreased to 30000 tonnes in 1991. In 1985 the use of crocidolite asbestos was stopped, and in 1999 the use of asbestoscontaining products was banned by law. During the years 1976-1996, 1520 cases of asbestos-related occupational diseases were diagnosed. This figure included 1314 cases of asbestosis, 154 cases of lung cancer, and 52 cases of pleura mesothelioma (Wozniak \& Wiecek, 2000).

A dose-response relationship between asbestos exposure and lung cancer has been proved, but no "safe level" has been determined. For example, one year of heavy exposure (e.g., manufacturing of asbestos products, asbestos spraying, insulation works with asbestos materials, demolition of old buildings) or 5 to 10 years of moderate exposure (e.g., construction, shipbuilding) may increase the lung cancer risk 2-fold or more. In some circumstances of extremely high asbestos exposure, a 2-fold risk of lung cancer can be attained with exposure of less than 1 year (Consensus report, 1997).

Risk of asbestos-related diseases increases with cumulative lifetime exposure to asbestos and rises also with increasing time interval (latency) since the first exposure. The results of the study of Pohlabeln et al. (2002) reveal a doubling of the cancer risk with 25 fibreyears of asbestos exposure. As a cumulative exposure exeeding 25 fibreyears $/ \mathrm{cm}^{3}$ causes a two-fold risk of lung cancer, the lung cancer of asbestos workers over this exposure is generally accepted as asbestos-related disease or occupational lung disease. The study of Boffeta (1998) shows that the risk of lung cancer seems to be linearly related to cumulative asbestos exposure, with an estimated increase in risk of $1 \%$ for each fibre $/ \mathrm{mL}$-year of exposure.

Persons exposed to industrial concentrations of asbestos have five times greater risk of developing lung cancer than nonexposed persons. The risk is not as great as for the cigarette smoker, who has a ten times greater risk than a nonsmoker. A sigarette smoker who also works with asbestos is more than 50 times more likely to contract lung cancer than a nonsmoking nonasbestos worker because asbestos and smoking have a synergistic effect on lung cancer risk.

Asbestos fibres are very thin and practically never settle. They can drift for long distances and can be transmitted to the employee's home on his clothes. It is not possible to assess asbestos exposure visually.

The aim of this research was to estimate the health risks related to asbestoscontaining dust in a cement factory.

\section{MATERIAL AND METHODS}

All the dust samples were collected in the asbestos-cement department using the Estonian standard method, a method developed in the former Soviet Union, which has been employed by other former East Bloc countries. With this method, samples were taken for 10 min every hour over a full shift of $8 \mathrm{~h}$. The sampling 
flow rate was $20 \mathrm{~L} / \mathrm{min}$, which gives a sampling velocity of $0.21 \mathrm{~m} / \mathrm{s}$ (SUSC, 1988). A total of 32 air samples ( 8 samples from each measuring point) were collected at different sites (operations) of the production line for determining levels of total dust $\left(\mathrm{mg} / \mathrm{m}^{3}\right)$.

The membrane filter method, widely accepted and used for the assessment of fibrous airborne dusts in the international occupational health practice, was introduced in Estonia at the beginning of the 1990s. Sampling and analyses were carried out according to the recommended technical method No. 1 (RTM-1), which was issued by the Asbestos International Association (AIA, 1988). The sampling rate was $2 \mathrm{~L} / \mathrm{min}$, which gives the sampling velocity of $0.07 \mathrm{~m} / \mathrm{s}$ for the filter. The sample flow rate was established at the beginning and checked at the end of each sample period with a film flowmeter. The membrane filters (mixed ester of cellulose) of $0.8 \mu \mathrm{m}$ porosity, mounted in an open-face filter holder and portable battery-operated pumps were used for air sampling. The determinations were made at a magnification of 400 using phase contrast illumination. Airborne asbestos dust collected on membrane filters appears in a wide variety of forms ranging from simple single fibres to very complex configurations of fibres or aggregates. The fibres with a maximum diameter less than $3 \mu \mathrm{m}$ and maximum length greater than $5 \mu \mathrm{m}$ and a length to diameter ratio greater than $3: 1$, and which do not appear to touch any particle with a maximum diameter greater than $3 \mu \mathrm{m}$ were counted. The Walton-Beckett circular eyepiece gradicule, type G-22 with $100 \pm 2 \mu \mathrm{m}$ projected diameter was used for counting the fibres. A total of 20 samples (4 samples each measuring point) were collected for the determination of airborne fibre concentrations (fibre $/ \mathrm{cm}^{3}$ ). All samples reported in this study were collected at a height of the breathing zone from the working environment. The sampling period started in February and ended in September 1993. Occupational exposure to total dust was assessed by the occupational hygienist V. Jaakmees, $\mathrm{PhD}$.

\section{RESULTS}

The highest fibre concentrations were observed at the beginning of the production line where asbestos was added manually from sacks and near the mixing mill where asbestos was mixed to cement: the airborne fibre concentrations varied between 0.97 and 6.90 fibres $/ \mathrm{cm}^{3}$. In the middle and at the end of the line the fibre concentrations were lower. The mean concentrations of airborne fibres (over $5 \mu \mathrm{m}$ in length) ranged from 0.02 to $4.40 \mathrm{fibres} / \mathrm{cm}^{3}$ and the concentrations of total dust fell from 1.2 to $8.6 \mathrm{mg} / \mathrm{m}^{3}$ (Table 1 ). Limit values of hazardous substances in the working environment are validated on the basis of the Act of Occupational Health and Safety with Resolution No. 293 of the Estonian Government (2001). According to it the limit value for asbestos (except crocidolite) in the workplace air is 0.1 fibres $/ \mathrm{mL}$. Before the adoption of this act the threshold limit values of the former Soviet Union were valid. According to these the maximum allowable concentration of asbestos dust in workplace air was $2 \mathrm{mg} / \mathrm{m}^{3}$ and asbestoscement dust $6 \mathrm{mg} / \mathrm{m}^{3}$. 
Table 1. Concentrations of airborne fibres and total dust in the asbestos-cement department

\begin{tabular}{l|c|c|c|c}
\hline \multirow{2}{*}{\multicolumn{1}{c}{ Measuring point }} & \multicolumn{2}{c|}{$\begin{array}{c}\text { Asbestos fibre concentration, } \\
\text { fibre } / \mathrm{cm}^{3}\end{array}$} & \multicolumn{2}{c}{$\begin{array}{c}\text { Total dust concentration, } \\
\mathrm{mg} / \mathrm{m}^{3}\end{array}$} \\
\cline { 2 - 5 } & Range & Mean $\pm \mathrm{SD}$ & Range & Mean $\pm \mathrm{SD}$ \\
\hline Dosing of raw asbestos & $1.50-5.90$ & $4.40 \pm 1.98$ & $2.10-9.70$ & $4.10 \pm 2.5$ \\
Mixing of asbestos and cement & $0.97-4.60$ & $3.10 \pm 1.58$ & $2.30-16.40$ & $8.60 \pm 3.9$ \\
Forming and cutting of & $0.36-0.69$ & $0.60 \pm 0.16$ & $2.20-4.30$ & $3.80 \pm 0.68$ \\
$\quad$ & & & & \\
$\quad$ asbestos-cement sheets & $0.01-0.09$ & $0.04 \pm 0.03$ & $1.00-1.50$ & $1.20 \pm 0.21$ \\
Packing of sheets & $0.01-0.03$ & $0.02 \pm 0.01$ & - & -
\end{tabular}

A cumulative exposure expressed in fibres per cubic centimetre per year (fibreyears) is an important parameter of asbestos exposure. Fibreyear is one year (240 working days) full-time ( 8 hours) work under asbestos exposure of $1 \times 10^{6} / \mathrm{m}^{3}$ asbestos fibres (length $>5 \mu \mathrm{m}$, diameter $<3 \mu \mathrm{m}$ ) in the air. Using mean asbestos fibre concentrations we can calculate a cumulative exposure in fibreyears (Table 2). A cumulative exposure over 25 fibreyears was detected when occupational exposure had been 10 years or more by exposure levels $\geq 3$ fibres $/ \mathrm{cm}^{3}$.

Table 2. Cumulative asbestos exposure (fibreyears)

\begin{tabular}{l|c|c|c}
\hline \multirow{2}{*}{$\begin{array}{c}\text { Exposure level, } \\
\text { fibre } / \mathrm{cm}^{3}\end{array}$} & \multicolumn{3}{|c}{ Duration of exposure, years } \\
\cline { 2 - 4 } & 10 & 20 & 30 \\
\hline \multirow{2}{*}{4.40} & $>25$ & $>25$ & $>25$ \\
3.10 & $>25$ & $>25$ & $>25$ \\
0.60 & $<10$ & $>10$ & $>10$ \\
0.04 & $<1$ & $<1$ & $>1$ \\
0.02 & $<1$ & $<1$ & $<1$
\end{tabular}

\section{DISCUSSION}

Asbestos has been used widely throughout several decades in Estonia. Therefore there have been uncontrolled exposures to airborne asbestos fibres. All diseases associated with asbestos exposure take many years to develop. The typical latency period is $20-30$ years. Risk assessment of developing asbestosrelated disease depends on dose, durability of the asbestos fibres (biopersistance), physical dimensions, and surface reactivity of inhaled materials. The use and sale of asbestos and asbestos-containing products are banned in several European countries, such as Denmark, Norway, Sweden, Finland, The Netherlands, Germany, Switzerland, Italy, France. However, cases of asbestos-related diseases are still 
increasing because of the widespread use of asbestos over the past years and the long latency period.

Asbestosis is generally associated with relatively high exposure levels (with radiological signs of parenchymal fibrosis). It can be estimated that $1-2 \%$ of workers will develop asbestosis in 30 years if the level of exposure is 1-2 fibres $/ \mathrm{cm}^{3}$. The performed investigations of the working environment during the processing of asbestos-cement sheets and a long-term use of asbestos suggest that some cases of asbestos-related diseases will be registred in the future. The health effects from asbestos exposure may continue to progress even after the exposure has ceased due to lodged fibers.

In 1987-1992, the Finnish Institute of Occupational Health implemented a nationwide asbestos programme. The goals were to minimize all exposure to asbestos, identify people exposed at work, and improve the diagnostics of asbestos diseases, especially cancer. The screening study of asbestos-induced diseases included 18943 current and retired workers from house building, shipyard, and asbestos industries. It was estimated that past exposure to asbestos among the Finnish population of 5 million causes $>150$ mesotheliomas and lung cancers annually, totalling $>2000$ asbestos-induced cancer deaths by the year 2010 (Huuskonen, 1995; Huuskonen et al., 1995).

Unfortunately, analogous data are missing in Estonia. The use of asbestos and asbestos-containing products peaked in the 1980s and fell at the beginning of the 1990s when the production of these materials was stopped in Estonia. So, we may suppose that asbestos-related diseases will reach their maximum in 2010 or somewhat later.

The use and import of asbestos and asbestos-containing products are prohibited in Estonia, but exposure continues to occur, for example, when asbestos-containing insulation or other asbestos materials are removed from older buildings and industrial plants. The ban on asbestos prevents risk from new exposures, but does not undo the damage from past exposure (manufacture, use, etc.).

At present the most important tasks for us are to inform the public, employers, and workers about asbestos-related health risks by using different possibilities for it, to establish a registry of asbestos-containing buildings, and to organize medical screening of workers exposed to asbestos.

\section{REFERENCES}

AIA. 1988. Reference method for the determination of airborne asbestos fibre concentrations at workplaces by light microscopy (membrane filter method). Recommended Technical Method No. 1 (RTM1). Asbestos International Association.

Boffeta, P. 1998. Health effects of asbestos exposure in humans: a quantitative assessment. Med. Lav., 89(6), 471-480.

Consensus report. 1997. Asbestos, asbestosis, and cancer: the Helsinki criteria for diagnosis and attribution. Scand. J. Work Environ. Health., 23, 311-316.

Egilman, D. \& Reinert, A. 1996. Lung cancer and asbestos exposure: asbestosis is not necessary. Am. J. Ind. Med., 30(4), 398-406. 
Eglite, M., Jekabsone, I., Jekabsone, J., Bake, M., Podniece, Z. \& Sprudza, D. 1998. Asbestos in Latvia. In Proceedings of the Asbestos Symposium for the Countries of Central and Eastern Europe 4-6 December 1997 Budapest, Hungary. People and Work. Research Reports (Lehtinen, S. et al., eds.), 19, 50-54. Helsinki.

Huuskonen, M. S. 1995. The Finnish Institute of Occupational Health (FIOH): Asbestos Program 1987-92. Eesti Töötervishoid, 2-3, 16-19.

Huuskonen, M. S., Koskinen, K., Tossavainen, A., Karjalainen, A., Rinne, J. P. \& Rantanen, J. 1995. Finnish Institute of Occupational Health Asbestos Program 1987-1992. Am. J. Ind. Med., 28(1), 123-142.

Kangur, M. 1996. Survey about asbestos problem in Estonia. Ecol. Med. Health Environ., 1, 71-75.

Kangur, M., Jaakmees, V., Moks, M., Kahn, H. \& Veidebaum, T. 1998. Asbestos in Estonia. In Proceedings of the Asbestos Symposium for the Countries of Central and Eastern Europe 4-6 December 1997 Budapest, Hungary. People and Work. Research Reports (Lehtinen, S. et al., eds.), 19, 39-43. Helsinki.

Landrigan, P. J., Nicholson, W. J., Suzuki, Y. \& Ladou, J. 1999. The hazards of chrysotile asbestos: a critical review. Ind. Health., 37(3), 271-280.

Loogna, N., Kahn, H., Kangur, M., Kasvand, M., Mae, S., Moks, M., Tatunts, E.-V., Tatar, T. \& Teichmann, M. 1996. Influence of Kunda Cement Factory to health of workers and local inhabitants. In Eesti Teadlaste Kongress (Congress of Estonian Scientists), 311. Teaduste Akadeemia Kirjastus, Tallinn.

Parker, J. E. 1997. Radiological criteria: the use of chest imaging techniques in asbestos-related diseases. Asbestos, asbestosis and cancer. In Proceedings of an International Expert Meeting 20-22 January 1997 Helsinki, Finland. People and Work. Research Reports (Lehtinen, S., ed.), 14, 28-40. Helsinki.

Pohlabeln, H., Wild, P., Schill, W., Ahrens, W., Jahn, I., Bolm-Audorff, U. \& Jockel, K. H. 2002. Asbestos fibreyears and lung cancer: a two phase case-control study with expert exposure assessment. Occup. Environ. Med., 59(6), 410-414.

Soviet Union Standard Committee (SUSC). 1988. General sanitary requirements for working zone air. No. 12.1.005-88 (in Russian).

Töökeskkonna keemiliste ohutegurite piirnormid. 2001. Riigi Teataja, 1, 77, 460.

Wagner, G. R. 1997. Asbestosis and silicosis. Lancet, 349, 1311-1315.

Wozniak, H. \& Wiecek, E. 2000. Chrysotile asbestos: biological effects, the work environment highest allowable concentration and neoplasm risk. Med. Pr., 51(3), 285-297.

\section{Retrospektiivne ülevaade töötajate eksponeeritusest asbesti sisaldavale tolmule tsemenditehases}

\section{Maie Kangur}

On esitatud andmed asbestikiudude ja üldtolmu sisalduse kohta õhus asbesttsementplaatide (eterniidi) valmistamisel. Õhuproovid nimetatud näitajate määramiseks võeti töökeskkonnast tootmisprotsessi normaalse töörežiimi korral. Kõrgeimad kontsentratsioonid leiti asbesti doseerimisel ja asbesttsemendisegu valmistamisel. Hinnati ka asbesti pikaajalisest kasutamisest tulenevat ohtu, kasutades kumulatiivset ekspositsiooni kiudaastates. Kumulatiivne ekspositsioon üle 25 kiudaasta leiti alates 10-aastase ekspositsiooni kestuse ja ekspositsioonitaseme $3 \mathrm{kiudu} / \mathrm{cm}^{3}$ ja enama korral. Käesoleval ajal on meil asbestikiude ning neid sisaldavaid tooteid keelatud kasutada ja müüa. 